\title{
Tax Research and Analysis Based on Seven Post Soviet-Union Countries
}

Guldjigitova Valeriya Andreevna"

DHU-UTS SILC Business School, Shanghai University, 20 Cheng Zhong Rd, Jiading, Shanghai, China

\author{
DOI: $\underline{10.36348 / \text { sjef.2020.v04i12.010 }}$ \\ | Received: 16.12 .2020 | Accepted: 24.12.2020 | Published: 30.12.2020
}

*Corresponding author: Guldjigitova Valeriya Andreevna

\section{Abstract}

This article is aimed at evaluating and comparison various scenarios of corporate income tax, individual income tax (personal income tax) and value added tax in listed below seven post-Soviet Union republics: Russian Federation, Republic of Belarus, Republic of Ukraine, Republic of Uzbekistan, Kazakhstan, Kyrgyzstan and Moldova. For many decades, economists from the European Union and the United States have regularly discussed such problems as building optimal tax systems, greening taxation, the effectiveness of tax reforms and others. Economists of the post-Soviet space in the 90s of the last century did not have such opportunity. At the same time, there was a very high need for scientific substantiation of the tax reforms being carried out in these countries. To fill this scientific gap, two economists Igor Mayburov from Russia and Yury Ivanov from Ukraine convened the first tax symposium in the post-Soviet space in 2009. Since then, the tax symposium has been annually held in different cities and brought together leading tax specialists from different countries. Each symposium has its own thematic focus, dedicated to the most relevant aspect of taxation for the post-Soviet countries. This scientific focus is declared one and a half years before the symposium. Symposium participants conduct research and thematic monographs are prepared for each symposium. XI International Symposium "Theory and Practice of Tax Reforms", held June 30 - July 62019 in Tomsk on the basis of the Institute of Economics and Management of the National Research Tomsk State University. These kind of symposiums have a major aim to understand, explain and find some new solutions to make the taxation system of post-Soviet Union republics more and more developed.

Keywords: Taxes, personal income tax, value added tax, corporate income tax, taxation.

Copyright () 2020 The Author(s): This is an open-access article distributed under the terms of the Creative Commons Attribution 4.0 International License (CC BY-NC 4.0) which permits unrestricted use, distribution, and reproduction in any medium for non-commercial use provided the original author and source are credited.

\section{Abbreviations}

CIT- Corporate Income Tax

IIT-Individual Income Tax

VAT- Value Added Tax

\section{INTRODUCTION}

Taxes culture is one of the main subsystem for economic culture of any country. Taxation of cooperatives in the post-Soviet space has both common features and some unusual features. This paper will be reinforced with some surveys made by the author according to the CIT, IIT and VAT in seven post-Soviet Union republics. Depending on the types of activities for cooperatives and approaches to taxation of various types of cooperatives in different post-Soviet countries they can be payers of both certain types and all of the above taxes [1-4].

It is known that the level of tax relations contributes to the growth of tax revenues, which in turn is the main item of income of the state budget. That is why the improvement of tax relations is among the key problems to be solved for the development of the country's economy $[5,6]$. In recent years, the society has been facing the need to renew the state strategy for the development of tax culture ever more urgently. The world experience of the country's governance aims at the need for a scientifically sound approach to a new national tax culture taking into account economic, financial, demographic, and social characteristics of the state [7-9].

\section{MATERIALS AND METHODS}

The first and most essential step of the paper will be comparison of tax rates related to the CIT, IIT and VAT.

For comparison, consider the rates of the main types of taxes applied in post-Soviet countries, the payers of which may be cooperatives.

As can be seen from the table below, there are seven countries, which have been involved in Soviet- 
Union, the major taxes, CIT, IIT and VAT are explored while the survey.

According to the table Russian Federation, Kazakhstan has the highest CIT rate, Ukraine has the highest IIT rate rate respectively.

However, Kyrgyzstan has the lowest CIT rate likewise the IIT rate is $10 \%$ along with Kazakhstan. The other aspect, that should be mentioned, that the lowest VAT rate has Kazakhstan and Kyrgyzstan.

Table-1: CIT, IIT and VAT rates

\begin{tabular}{|l|l|l|l|}
\hline Country & CIT & IIT & VAT \\
\hline Russian Federation & $20 \%$ & $13 \%$ & $20 \%$ \\
\hline Belarus & $18 \%$ & $13 \%$ & $20 \%$ \\
\hline Ukraine & $18 \%$ & $18 \%$ & $20 \%$ \\
\hline Kazakhstan & $20 \%$ & $10 \%$ & $12 \%$ \\
\hline Uzbekistan & $12 \%$ & $12 \%$ & $15 \%$ \\
\hline Kyrgyzstan & $10 \%$ & $10 \%$ & $12 \%$ \\
\hline Moldova & $12 \%$ & $12 \%$ & $20 \%$ \\
\hline
\end{tabular}

In general, the analysis of tax systems shows that the tax burden in post-Soviet countries in comparison with many other countries of the world relatively low.

The cooperative laws of post-Soviet countries often describe conceptual principles and offer guidance on taxing different types of cooperatives, but ultimately any tax rules are based on the Tax Code of each country. For example, the Kyrgyz Law on Cooperatives contains a general statement that all decisions related to the taxation of cooperatives are made on the basis of the Tax Code (Art. 32).

The norms that to some extent regulate the taxation of cooperatives are available in the Tax Codes of most post-Soviet countries, except for Armenia, Azerbaijan, Tajikistan, Turkmenistan and Uzbekistan, where cooperatives are taxed on a general basis, taking into account the specifics established by special legislation.

Below the author proposes to consider the characteristics of VAT and income tax, as well as other types of taxes in post-Soviet countries, which in one way or another relate to agricultural cooperatives and their members.

\section{INCOME TAX}

Income tax is an essential part of the tax system of states and is intended to perform not only a fiscal function, but also to contribute to the solution of socio-economic problems. Recognized in the world to achieve these goals is a progressive scale of taxation of income of its citizens.
In the post-Soviet countries, the role of personal income taxation is not prevalent, unlike in many other countries of the world, due to the relatively low income level of the bulk of the population and the high shadow wages (wages "in envelopes"). It should be noted that in the post-Soviet states, the progressive scale of taxation was in effect until the beginning of the 21 st century.

Since 2001, the Russian Federation was the first of the post-Soviet countries to switch to a "flat" scale of taxation, then to the Republic of Belarus, the Republic of Kazakhstan, the Kyrgyz Republic and Ukraine switched to a flat scale (since January 1, 2011, Ukraine has switched to a two-stage scale).

The tax systems of the CIS countries have a flat scale of taxation. This means that the tax rate is the same for a person regardless of their income. In Georgia, personal income tax is $20 \%$, in Belarus $13 \%$, in Lithuania - 15\%, in Ukraine - 18\%. The lowest is in Kazakhstan $-10 \%$. But in most countries of the world there is a progressive tax on income: the higher the earnings, the higher the rate.

This tax is to a large extent important for production cooperatives, since the members of these cooperatives are required to accept direct labor participation in the economic activities of the cooperative, respectively, the amounts should be included in the salary fund of the cooperative of this tax, as well as the corresponding contributions to social and insurance funds, provided for by the legislation of each individual country.

It should be noted that for individual payers and (or) types of activities, the legislation of a particular country may establish fixed payments that replace income tax.

\section{VALUE ADDED TAX (VAT)}

Value added tax (VAT) is one of the most widespread indirect taxes in the world and is included in the tax systems of more than 100 countries. In some cases, for example, in the USA and Armenia, sales or turnover tax is applied instead of VAT.

Cooperatives as legal entities, according to general rules, charge VAT on all their transactions. This has little impact on legal entities doing business with a cooperative - such as registered peasant farms, other cooperatives, or agricultural enterprises. In accordance with generally accepted VAT procedures, these entities simply offset between the VAT charged and their own aggregate VAT liabilities, while the cooperative offset between the VAT charged by its customers and its own aggregate VAT liabilities. 
Cooperative lobbyists in post-Soviet countries advocate that all transactions with members be exempt from VAT. For many years, the Tax Code of Moldova has had a provision on exemption of agricultural service cooperatives from VAT on transactions with members (see version 2013, part III, chapter 4, art. 103 (1): 22). In the Kyrgyz Tax Code, agricultural service cooperatives are also exempt from VAT on transactions with members (Article 239). The same point of view was shared by the drafters of the 2013 Law on Cooperatives in Tajikistan, who prepared a draft amendment to Tax code. Attempts to partially solve this problem were made in Kazakhstan, where service cooperatives were provided with preferential conditions for the payment of only $30 \%$ of the total amount of VAT, as well as in Ukraine, where the new concept VAT in agriculture allows agricultural cooperatives that register voluntarily or according to the requirements of the legislation as a VAT payer (along with any other agricultural manufacturers), accumulate their VAT liabilities for internal development purposes instead of transferring them to the state. These solutions are effective for legal entities, but not for small farmers. VAT bias towards small farmers can only be eliminated through the adoption of clear legislation to exempt from VAT all transactions of the cooperative with its members [10].

For instance, in the Republic of Uzbekistan, economic entities operate in different tax regimes. So, in particular, for business entities the system of generally established taxes is applied, but for certain categories of entities there are special taxation regimes. The generally established system of taxes provides for the payment of VAT. Special taxation regimes do not provide for the payment of VAT. However, business entities applying special taxation regimes pay VAT to sellers when purchasing material resources and, together with VAT, attribute them to the cost price. As a result, the products manufactured by such enterprises become more expensive and uncompetitive [11].

This situation negatively affects the economic relations of these entities and leads to an increase in the cost of production and a reduction in the rate of profit received, an increase in the tax burden on payers of national taxes. Similar problems are noted in other countries that provide VAT exemption for small entrepreneurs. However, in most countries this problem is not so acute.

According to the present Tax Code rules in the Republic of Uzbekistan, VAT tax must be payed if your company's revenue is up to $100000 \$$ per year, otherwise you are not VAT payer.

\section{CORPORATE INCOME TAX}

Corporate Income tax (in a number of countries - corporate tax), along with other taxes, plays a hugest and major role of filling budgets, also serves as one of the main instruments for regulating the development of priority sectors of the economy for the state. Currently, in the post-Soviet and other countries of the world, various rates of this tax are applied. As a rule, in the developed countries of Europe, the level of taxation of corporate profits is higher than in countries with less developed economies.

The general trend related to the development of corporate come tax in the world is a dramatic drop of the CIT rate in most countries (in England, Germany, Poland, South Korea, Czech Republic, Japan), due to the need to create favorable, highly competitive conditions for economic growth and attracting investment. At the same time, almost all countries in the world rather use preferential taxation regimes, in order to solve urgent economic problems and cancel those regimes as soon as the problems will be determinate. For example, a variety of tax incentives for newly created cooperatives operate in Holland, France, Poland and other developed countries.

In the Republic of Belarus, the standard corporate income tax rate is $18 \%$. The CIT rate for dividends is set at $12 \%$. The profit of organizations received from the sale of goods of their own production, included in the list of high-tech goods, if the share of proceeds received from the sale of such goods is not more than $50 \%$ of the total amount of proceeds received from the sale of goods (works, services), property rights, including income from leasing (financial lease (leasing)) property is subject to income tax at a rate of $10 \%$. Along with reduced rates for income tax, incentives are applied in the form of exemption from income tax in certain cases.

Income tax in Kyrgyz Republic is $10 \%$. From 1 January 2013, the income tax rate of a taxpayer carrying out certain priority activities for the country is set at $0 \%$. Established by the new edition of the Tax Code of Kyrgyz Republic, the liberal tax the regime for entrepreneurs and investors is important for their involvement in the legal field of activity, reducing the share of the shadow economy, increasing production volumes and, accordingly, stimulates the growth of tax revenues to the country's budget.

In Russia, the base income tax rate in 2014 was unchanged at 20\%. From January 1, 2014, amendments to the Tax Code of the Russian Federation came into force: in terms of stimulating the implementation of regional investment projects in the territories of individual constituent entities of the Russian Federation to create favorable tax conditions in order to carry out investment activities and support the creation of new industrial enterprises and high-tech projects, including in the Far Eastern Federal District A separate mechanism that stimulates investments is the right of the constituent entities of the Russian Federation to reduce the profit tax rate in the part 
credited to the budget of the constituent entity, from $18 \%$ to $13.5 \%$ (clause 1 of article 284 of the Tax Code of the Russian Federation). In a number of constituent entities of the Russian Federation, the tax rate has been lowered for organizations implementing significant investment projects.

In Ukraine, the income tax rate in 2013 was reduced to $19 \%$, and to $18 \%$ in 2014 , the same base rate is provided for 2015 . The previous $5 \%$ income tax rate for subjects of the software industry has been canceled. Taxation of profit received from the implementation of investment projects by business entities that are implemented in priority sectors of the economy is carried out at the following rates: from January 1, 2013 to December 31, 2017 - 0\%; from January 1, 2018 to December 31, 2022 - 8\%; from January 1, 2023 - 16\%.

In terms of Uzbekistan, the CIT rate has been droped from $38 \%$ from 1991 to $12 \%$ in 2020. According to the Tax Code of the Republic of uzbekistan, the payers of CIT are legal entities with taxable income (profit) in the financial year. The foreign entities and entities, who has special taxation procedure, are not CIT payers.

The role of corporate income tax is especially important in the process of redistributing funds between sectors of the economy for their proportional development, as well as enhancing investment policy. At the same time, the greatest effect of the development of investment policy, as a rule, is achieved not by reducing tax rates, but by using targeted tax incentives. These include accelerated depreciation, tax credit and other measures used to stimulate economic investment activity.

\section{CONCLUSION}

Summing up, the author would like to note that a systematic analysis of the laws and tax codes of postSoviet countries, which also concern the taxation of agricultural cooperatives, allows us to conclude that in most cases the legislation of the post-Soviet countries does not have strong differences among themselves, as in the procedure for determining the base and methods of taxation, and in determining the tax rate itself. In most cases, states set approximately the same tax rates and make it possible to take advantage of various benefits in the calculation and payment of a particular type of tax. Also noteworthy is the fact that the legislation of some countries contains provisions on exemption from taxes on dividends and interest of members of cooperatives, which in turn stimulates the development of agriculture.

\section{REFERENCES}

1. Deloitte., \& Touche, L. L. C. (2019). Online and web site deloitte.kg, 2019.

2. Davnis, V. V., \& Rodin, V. A. (2016). Modeling of the Progressive Taxation in Regions of Russia. Modern Economics: problems and solutions. (3):8-19. (In Russ.)

3. Egorova O. Y., \& Smirnova E. E. Tax Risk Management in a Company in Conditions of Economic Instability. Available at: https://nauchforum.ru/archive/MNF_social/2(21).p df (In Russ.)

4. Balatsky, E. V., \& Ekimova, N. A. (2019). Evaluating scenarios of a personal income tax reform in Russia. 2019.

5. Mayburov, I. A. (2019). Challenges and Prospects of Taxation in the Digital Economy: Symposium "Theory and Practice of Tax Reforms" as a Case of Focused Discussion in the Post-Soviet Space. 2019.

6. Mayburov, I., \& Ivanov, Y. (eds.). (2016). Encyclopedia of theoretical foundations of taxation. Moscow: UNITY DANA. (In Russ.).

7. Mayburov, I., \& Ivanov, Y. (eds.). (2019). Taxes in the digital economy. Theory and methodology. Moscow: UNITY DANA. (In Russ.).

8. Taxation Guide of foreign individuals in Uzbekistan. Article written by Deloitte \& Touche, LLC. Online and web site resource www2.deloitte.com/kz/en/pages/uzbekistan/article s/uz-tax-foreigners.html. 2015.

9. Polterovich, V. (2007). Elements of reform theory. Moscow: Ekonomika. (In Russ.).

10. Timergaziz Gabidullovich Sadykov, Tax Culture the Basis of Russian Tax System. 2020.

11. Kuzieva, N. R. (2019). Free economic zones of Uzbekistan: development, operation and features of the tax regime. April 2019. 